\title{
EXPLOSIVE STRENGTH TRAINING IMPROVES SPEED AND AGILITY IN WHEELCHAIR BASKETBALL ATHLETES
}

\author{
TREINAMENTO DE FORÇA EXPLOSIVA MELHORA A VELOCIDADE E A AGILIDADE DE ATLETAS \\ DE BASQUETEBOL EM CADEIRAS DE RODAS \\ ENTRENAMIENTO DE FUERZA EXPLOSIVA MEJORA LA VELOCIDAD Y LA AGILIDAD DE ATLETAS \\ DE BÁSQUETBOL EN SILLAS DE RUEDAS
}

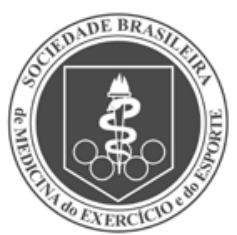

Original Article

\begin{abstract}
Tarik Ozmen' (Physiotherapist) Bekir Yuktasir² (Physical Educator) Necmiye Un Yildirim² (Physiotherapist) Birol Yalcin² (Physical Educator) Mark ET Willems ${ }^{3}$

(Exercise Physiologist)

1. Karabuk University, Karabuk, Turkey. 2. Abant Izzet Baysal University, Bolu, Turkey.

3. University of Chichester, Chichester, United Kingdom.

Work performed at School of Health, Karabuk University, Karabuk, Turkey.
\end{abstract}

\section{Correspondence:}

Department of Physiotherapy and Rehabilitation, School of Health, Karabuk University, 78050 Karabuk, Turkey.

tarikozmen@karabuk.edu.tr

\begin{abstract}
Introduction: Wheelchair basketball is a paralympic sport characterized by intermittent high-intensity activities that require explosive strength and speed. Objective: To investigate the effect of explosive strength training on speed and agility performance in wheelchair basketball players. Methods: Ten male wheelchair basketball players ( $\mathrm{M}_{\mathrm{age}}=31 \pm 4 \mathrm{yrs}$ ) were divided into two groups [i.e. explosive strength training (ES); control (CN)] based on International Wheelchair Basketball Federation (IWBF) classification scores. The ES group underwent 6-weeks of training, twice weekly, at 50\% 1RM, 10-12 repetitions and 3-4 sets in addition to routine training. Effects of training were measured by the $20 \mathrm{~m}$ sprint test and Illinois agility test. Results: The ES group, showed significantly higher increases in speed and agility performance $(p \leq .05)$. Conclusion: A short-duration (i.e. 6-week) explosive strength training programme in wheelchair basketball athletes results in significant improvements in sprint and agility performance.
\end{abstract}

Keywords: wheelchair basketball, strength training, speed, agility.

\section{RESUMO}

Introdução: O basquete em cadeira de rodas é um esporte paralímpico caracterizado por atividades intermitentes de alta intensidade que exigem força explosiva e velocidade. Objetivo: Investigar o efeito do treinamento de força explosiva sobre a velocidade e o desempenho da agilidade em jogadores de basquete em cadeira de rodas. Métodos: Dez jogadores de basquete do sexo masculino em cadeira de rodas ( $M_{i d a d e}=31 \pm 4$ anos) foram divididos em dois grupos [ou seja, treinamento de força explosiva (FE) e controle (CN)], com base em cadeira de rodas de acordo com os escores de classificação da Federação Internacional de Basquetebol em Cadeira de Rodas (IWBF). $O$ grupo FE realizou 6 semanas de treinamento, duas vezes por semana, a 50\% de 1RM, 10-12 repetições e 3-4 séries, além de treinamento de rotina. Os efeitos de treinamento foram medidos pelo teste de corrida de 20 metros (sprint test) e pelo teste de agilidade de Illinois. Resultados: O grupo FE mostrou aumentos significantemente maiores de velocidade e desempenho de agilidade ( $p \leq 0,05$ ). Conclusão: A curta duração (isto é, 6 semanas) do programa de treinamento de força explosiva em atletas de basquetebol em cadeira de rodas resulta em melhorias expressivas do desempenho na corrida e de agilidade.

Palavras-chave: basquetebol, treinamento de força, velocidade, agilidade.

\section{RESUMEN}

Introducción: El básquetbol en silla de ruedas en el deporte paraolímpico caracterizado por actividades intermitentes de alta intensidad, las cuales exigen fuerza explosiva y velocidad. Objetivo: Investigar el efecto del entrenamiento de fuerza explosiva sobre la velocidad y el desempeño de la agilidad en jugadores de básquetbol en silla de ruedas. Métodos: Diez jugadores de básquetbol del sexo masculino en silla de ruedas (Promedio $_{\text {edad }}=31 \pm 4$ años) fueron divididos en dos grupos [o sea, entrenamiento de fuerza explosiva (FE) y control (CN)], con base en silla de ruedas, de acuerdo con las puntuaciones de clasificación de la Federación Internacional de Baloncesto en Silla de Ruedas (IWBF). El grupo de FE realizó 6 semanas de entrenamiento, dos veces por semana, a 50\% de 1RM, 10-12 repeticiones y 3-4 series, además de entrenamiento de rutina. Los efectos del entrenamiento fueron medidos mediante la prueba de carrera de 20 metros (sprint test) y por la prueba de agilidad de Illinois. Resultados: El grupo de FE mostró aumentos significantemente mayores de velocidad y desempeño de agilidad ( $p \leq 0,05$ ). Conclusión: La corta duración (es decir, 6 semanas) del programa de entrenamiento de fuerza explosiva, en atletas de básquetbol en silla de ruedas, resultó en mejorías expresivas del desempeño en la carrera y de agilidad.

Palabras clave: básquetbol, entrenamiento de fuerza, velocidad, agilidad. 


\section{INTRODUCTION}

Exercise and sports may be more important for individuals with disabilities because of their limited physical activity. In people with disability, sport and exercise participation can improve both physical and psychological health problems ${ }^{1,2}$. Furthermore, participation in sports can lead to an increase in self-esteem, self-efficacy, quality of life and reduction of anxiety'. Physical activity and sport is also an important indicator of productivity for wheelchair users ${ }^{3}$. Wheelchair users who participated in sports activities were reported to develop muscle strength, cardiorespiratory endurance and bone mineral density ${ }^{4-7}$.

Wheelchair basketball (WCB) is a paralympic sport with increasing world-wide popularity in recent years, with participation of individuals that have different disabilities such as spinal cord injury, poliomyelitis, spina bifida and amputation. The sport is characterized by intermittent high-intensity activities like wheelchair maneuvering and ball handling ${ }^{8,9}$. Wheelchair maneuvers may include propulsion, starting, stopping, and direction changes of the wheelchair, activities that require explosive strength and speed. Agility is defined as a rapid whole body movement, involving a change of velocity or direction, in response to a sport specific stimulus ${ }^{10}$. According to this definition, agility in WCB would allow fast direction changes of the wheelchair. Ball handling may include shooting, passing, dribbling, rebounding and shooting above the head level with similtaneous manipulation of the wheelchair during the game. Therefore, upper-extremity muscle strength is important for wheelchair athletes ${ }^{11,12}$. It is likely that strength training in WCB athletes may enhance sports performance as well as prevention of sport injuries ${ }^{13}$. In addition, Olenik et al. ${ }^{14}$ reported that strengthening and stretching exercises may be beneficial to correct imbalances of the muscles in the upper extremity. Some studies have examined the effect of circuit training training and rehabilitation in wheelchair users ${ }^{15,16}$, but there is a lack of studies on strength training in WCB athletes ${ }^{17}$. As far as we know, no studies have reported the effects of short-duration explosive strength training in WCB athletes.

The purpose of this study was to examine to effects of 6-weeks explosive strength training on sprint speed and agility performance in wheelchair basketball players.

\section{METHODS}

Ten male competitive wheelchair basketball players $\left(\mathrm{M}_{\mathrm{age}}=31 \pm\right.$ 4 years, age range 21-36 years) participated in the study. The disabilities of the participants included spinal cord injury $(\mathrm{SCl})$ and post polio (table 1). All participants were highly trained and competed regularly in wheelchair basketball competitions at a National level or above for at least two years. They trained three times per week routinely. The study was approved by the University Ethics Committee and participants' informed consent was obtained prior to data collection.

\section{MATERIAL AND PROCEDURE}

Before testing, participants were given practice trials to become familiar with the testing procedures.

Speed. Speed was determined by a $20 \mathrm{~m}$ sprint test on wheelchair running line ${ }^{18}$. The players had two attempts to cover the $20 \mathrm{~m}$ distance as quickly as possible within a 2-min period. Duration of the sprint was measured by using photocell gates (Newtest Oy, Oulu, Finland) located at the beginning and the end of this line and the best time (in seconds) was taken.

Agility. Agility was evaluated using the Wheelchair Illinois Agility Test $^{19}$. The course on basketball court had a length and width of $10 \mathrm{~m}$ and $5 \mathrm{~m}$, respectively. Four cones marked the start, finish and the two turning points. Another four cones were placed down the center an equal distance apart. Each cone in the center was spaced $3.3 \mathrm{~m}$ apart. The players were instructed to drive their wheelchair as quickly as possible around the course in the direction indicated to the finish line. The duration was measured by photocells located from start to finish with the best result of two attempts recorded.

Players were divided into two equal groups according to the sum of the International Wheelchair Basketball Federation (IWBF) classification scores: the explosive strength (ES) and control (C) group. The ES group underwent 6-weeks of training, twice weekly, at 50\% the one-repetition maximum (1-RM), 10-12 repetitions and 3-4 sets in addition to routine training. The 1-RM values in six exercise stations were determined for the ES group before the ES training. The participants were familiarized at six exercise stations including bench press, biceps curl, shoulder press, pec dec, lateral pull-down and triceps extension. Prior to beginning the test, the participants were allowed several warm-up repetitions at each station. After a two-minute rest period, the players were instructed to try to perform as much repetitions as possible with a starting weight. When they were able to lift more than ten repetitions, lifting was stopped and continued after a rest period with an increase in weight. A maximum of three attempts was allowed. The 1-RM values were calculated using following the Brzycki $^{20}$ regression equation.

$1-\mathrm{RM}=100 \times$ load repetition $/(102.78-2.78 \times$ repetition $)$

Where:

- load repetition: workload value of repetitions performance, expressed in $\mathrm{kg}$;

- repetition: number of repetitions performed.

The ES training was implemented for 6-weeks, twice weekly, at 50\% 1-RM with 10-12 repetitions and 3-4 sets. All training occured in-season. The explosive strength training program consisted of 6 six exercise stations: bench press, biceps curl, shoulder press, pec dec, lateral pull-down and triceps extension. The rest period for set intervals was 2 mins and 1 min for exercise intervals. During the first two weeks of training, three sets of 10 repetitions were performed. This was increased during the following four weeks to four sets of 12 repetitions. All training sessions were supervised. None of the players participated in any other type of resistance training for the upper extremities and were not taking any medications or anabolic steroids known to affect strength performance.

\section{Statistical Analysis}

The statistical program SPSS 11.0 for Windows was used for data analysis. Demographic data (mean and standard deviations) were calculated for all variables. Data from pre-test and post-test were compared with the Wilcoxon Matched Pairs Signed-Rank test within each group. The Mann-Whitney $U$ test was used to compare the two groups. Statistical significance was set at $p \leq .05$.

\section{RESULTS}

The demographic data of participants are shown in table 1. Speed and agility data are shown in table 2 . The Mann Whitney U Test did not indicate a significant difference between the two groups for the pre-test sprint and agility $(p \leq .05)$. Both the ES and CN group showed significant improvements in speed and agility $(p \leq .05)$. However, the Mann Whitney $U$ Test revealed that the improvements were significant higher for the ES group ( $p \leq .05$ ) (table 3 ). 
Table 1. Demographic data for the explosive strength (ES) and control group (CN).

\begin{tabular}{c|c|c|c}
\hline Variables & $\begin{array}{c}\text { ES Group ( } \mathbf{n = 5 )} \\
\mathbf{M}(\mathbf{S D})\end{array}$ & $\begin{array}{c}\text { CN Group ( } \mathbf{n}=\mathbf{5}) \\
\mathbf{M}(\mathbf{S D})\end{array}$ & $\mathbf{p}$ \\
\hline Age (years) & $31(6)$ & $32(2)$ & 0.751 \\
\hline Sport experience (years) & $8.0(5.2)$ & $11.6(6.3)$ & 0.295 \\
\hline IWBF Classification score & $3.10(1.08)$ & $3.10(1.19)$ & 0.827 \\
\hline
\end{tabular}

IWBF = International Wheelchair Basketball Federation.

Table 2. Pre-and post-test sprint and agility mean performance scores of the groups.

\begin{tabular}{|c|c|c|c|c|c|}
\hline \multicolumn{2}{|c|}{ Groups } & $\begin{array}{c}\text { Pre-test (s) } \\
M \text { (SD) }\end{array}$ & $\begin{array}{c}\text { Post-test (s) } \\
M(S D)\end{array}$ & Change (\%) & $p$ \\
\hline \multirow{2}{*}{ ES Group $(n=5)$} & Sprint & $4.74(0.19)$ & $4.62(0.13)$ & 2.53 & $0.043^{*}$ \\
\hline & Agility & $26.39(0.86)$ & $25.92(1.02)$ & 1.78 & $0.042^{*}$ \\
\hline \multirow{2}{*}{ CN Group $(n=5)$} & Sprint & $4.89(0.25)$ & $4.85(0.24$ & 0.81 & $0.043^{*}$ \\
\hline & Agility & $26.84(1.75)$ & $26.68(1.73)$ & 0.59 & $0.041^{*}$ \\
\hline
\end{tabular}

* Statistically significant difference $(p<0.05)$.

Table 3. Comparison of differences sprint and agility scores between pre-and post-test of the groups.

\begin{tabular}{c|c|c|c}
\hline & ES Group $(\mathbf{n = 5})$ & CN Group $(\mathbf{n = 5})$ & $\mathbf{p}$ \\
\hline Sprint & $0.11 \pm 0.06$ & $0.04 \pm 0.01$ & $0.009^{*}$ \\
\hline Agility & $0.46 \pm 0.22$ & $0.15 \pm 0.06$ & $0.008^{*}$ \\
\hline
\end{tabular}

* Statistically significant difference $(p<0.05)$.

\section{DISCUSSION}

The novel finding of the present study was that short-duration explosive strength training resulted in significant improvements in speed and agility performance in wheelchair basketball athletes. The training was designed at moderate intensity to reduced the risk for injuries. It has been reported that low intensity strength exercises were beneficial for rehabilitation of injuries ${ }^{16,21}$.

Previous studies on strength training in wheelchair users were aimed to rehabilitate and to cope with the challenges of daily life with focus to maintain fitness level and increase functional independence. In those studies, training consisted of moderate intensity exercises with arm, kayak and wheelchair ergometers ${ }^{15-17}$. Especially, individuals with SCl have physiological disavantages limiting exercise capacity. For example, the direct loss of motor control and sympathetic nervous system activity below the level of lesion may cause relatively low va- lues of oxygen uptake in individuals with $\mathrm{SCl}$. These impairments are associated with reduced maximal heart rate, lower stroke volume, venous pooling in the lower limbs because of reduced muscular pump, slower increase of oxygen consumption during steady-state exercise, and impaired thermoregulation 9,22,23. Despite these physiological responses, studies have shown improvements in muscle strength in the upper extremities in sedentary individuals with $\left.\mathrm{SC|}\right|^{15,24}$. For example, Jacobs, Nash, and Rusinowski ${ }^{15}$ used a training programme over 12-weeks, three times a week at 50\% 1-RM in 10 sedentary individuals with $\mathrm{SCl}$ using military press, horizontal rows, pec dec, preacher curls, wide grip latissimus pull-down and eated dips. Another study by Nash et al. ${ }^{16}$ used a 16-weeks programme, three times a week, 50\% 1-RM in seven individuals with $\mathrm{SCl}$, with military press, horizontal rows, pectoralis, preacher curls, wide grip latissimus pull-down and seated dips. Bjerkefors, Jansson, and Thorstensson ${ }^{24} 10$-week, three times a week, 10 sedentary individuals with $\mathrm{SCl}$ using kayak ergometer.

WCB is a physically demanding team sport that requires a high degree of skill, technical expertise, and teamwork. Acceleration, speed, and agility are of particular importance since the game is often played at a fast pace, and excellent chair and ball skills are fundamental to the game. A high level of conditioning is required to maintain work intensity and to prevent injury9. Upper-extremity muscle strength is important for wheelchair athletes ${ }^{11,12}$. In WCB, upper extremity muscles serves both ball handling and wheelchair mobilization. Explosive strength development may increase competition performance of the WCB players, however, we can only speculate whether the speed and agility performance would improve play during competition. Explosive strength training in WCB athletes may have lead to specific neural adaptations, such as an increased rate of activation of motor units. The duration of the explosive strength training is unlikely to have resulted in muscle hypertrophy as in common with heavy resistance training ${ }^{25-27}$. The neural adaptations such as an increased motor unit synchronization and firing rate may have contributed to the improvement of speed. It is very likely that the development of strength was the result of neural adaptations because the training period was shorter than eight weeks. The role of these adaptions is well recognized during the early phase of strength training. Other studies have shown the importance of upper extremity strength in wheelchair users. Janssen et al..$^{28}$ demonstrated that there is a strong positive association between upper-body isometric strength and sprint power. Tupling et al. ${ }^{11}$ showed that the initiation of wheelchair movement depends on upper-extremity strength. Van Der Woude et al. ${ }^{29}$ reported that sprint performance is related to disability level and wheelchair propulsion technique. Turbanski and Schmidtbleicher ${ }^{21}$ trained 8 wheelchair athletes with $\mathrm{SCl}$ and 8 healthy physical education students at high intensity. The 8-week training programme was at 80\% of 1-RM, twice a week, with 10 to 12 repetitions in 5 sets using bench press exercise, and resulted in a decrease by $6.2 \%$ of the $10-\mathrm{m}$ sprinting time of eight wheelchair athletes and healthy controls. Our data showed that explosive strength training improved sprint speed by $2 \%$ for a $20-m$ distance. Our lower improvement in sprint speed than in the study by Turbanski and Schmidtbleicher ${ }^{21}$ may be related to a shorter training duration and intensity of training. Differences in adaptations may also be due to the different training experience of partcipants. For example, Van Den Berg et al. ${ }^{30}$ used a 7-week low-intensity (30\% of maximum heart rate) hand rim wheelchair training in 10 able-bodied participants. Although these authors reported a $31.2 \%$ increase in sprint power, this improvement may be related to the facts that the participants were sedentary and did not have wheelchair experience use before the study. In our study, the control group consisted of trained WCB athletes. 


\section{CONCLUSION}

In conclusion, a short duration explosive strength training programme of the upper extremity resulted in significant improvements in sprint speed and agility performance in WCB athletes. Upper-extremity muscle strength is very important for wheelchair basketball athletes in competition. For this reason, the training program of WCB athletes as used in this study may be advised to improve competition performance. However, future studies should examine whether strength training programmes will enhance competition performance in WCB athletes. A potential limitation of our study was the small sample size as well as having highly trained WCB athletes with different disabilities. However, significant improvements in sprint speed and agility were observed.

All authors have declared there is not any potential conflict of interests concerning this article.

\section{REFERENCES}

1. Campbell E, Jones G. Psychological well-being in wheelchair sport participants and nonparticipants. Adapt Phys Activ Q. 1994;11(4):404-15.

2. Giacobbi PR, Stancil M, Hardin B, Bryant L. Physical activity and quality of life experienced by highly active individuals with physical disabilities. Adapt Phys Activ Q. 2008;25:189-207.

3. Noreau L, Shephard RJ. Physical fitness and productive activity of paraplegics. Res Sports Med. 1992;3:165-81.

4. Hicks AL, Martin KA, Ditor DS, Latimer AE, Craven C, Bugaresti J, McCartney N. Long-term exercise training in persons with spinal cord injury: effects on strength, arm ergometry performance and psychological well-being. Spinal Cord. 2003;41:34-43.

5. Margonato V. Effects of training on cardiorespiratory fitness and lipidic profile of paraplegics. Sport Sci Health. 2008;3:7-9.

6. Miyahara K, Wang D, Mori K, Takahashi K, Miyatake N, Wang, B., Takigawa, T., Takaki J, Ogino K. Effect of sports activity on bone mineral density in wheelchair athletes. J Bone Miner Metab. 2008;26:101-6

7. Schmid A, Huonker M, Stober P, Barturen JM, Schmidt-Trucksäss A, Dürr H, Völpel, HJ, Keul J. Physical performance and cardiovascular and metabolic adaptation of elite female wheelchair basketball players in wheelchair ergometry and in competition. Am J Phys Med Rehabil 1998;77(6):527-33.

8. Coutts KD. Dynamics of Wheelchair Basketball. Med Sci Sports Exerc. 1992;24(2):231-4

9. Goosey-Tolfrey V. Wheelchair Sport. Champaign, IL: Human Kinetics, 2010.

10. Sheppard JM, Young WB, Doyle TL, Sheppard TA, Newton RU. An evaluation of a new test of reactive agility and its relationship to sprint speed and change of direction speed. J Sci Med Sport. 2006;9(4):342-9.

11. Tupling SJ, Davis GM, Pierrynowski MR, Shephard RJ. Arm strength and impulse generation: Initiation of wheelchair movement by the physically disabled. Ergonomics.1986;29(2):303-11.

12. Wang YT, Chen S, Limroongreungrat W, Change LS. Contributions of selected fundamental factors to wheelchair basketball performance. Med Sci Sports Exerc. 2005;37(1):130-7.

13. Finley MA, Rodgers MM. Prevalence and identification of shoulder pathology in athletic and nonathletic wheelchair users with shoulder pain. J Rehabil Res Dev. 2004;41(3):395-402.

14. Olenik LM, Laskin JJ, Burnham R, Wheeler GD, Steadward RD. Efficacy of rowing, backward wheeling and isolated scapular retractor exercise as remedial strength activities for wheelchair users. Paraplegia. 1995;33:148-52.

15. Jacobs PL, Nash MS, Rusinowski JW. Circuit training provides cardiorespiratory and strength benefits in persons with paraplegia. Med Sci Sports Exerc. 2001;33(5):711-7.
16. Nash MS, Van De Ven I, Van Elk N, Johnson BM. Effect of circuit resistance training on fitness attributes and upper-extremity pain in middle-aged men with paraplegia. Arch Phys Med Rehabil. 2007;88:70-5

17. Davis GM, Shephard MD. Strength training for wheelchair users. Br J Sports Med. 1990;24(1):25-30

18. Vanlandewijck YC, Daly DJ, Theisen DM. Field test evaluation of aerobic, anaerobic, and wheelchair basketball skill performances. Int J Sports Med. 1999;20(8):548-54.

19. Chapman D, Fulton S, Gough C. Anthropometric and physical performance characteristics of elite male wheelchair basketball athletes. J Strength Cond Res. 2010; 24, supplement p 1. Abstract retrieved from http://journals.Iww.com, doi: 10.1097/01.JSC.0000367081.53188.ba

20. Brzycki M. Strength testing: predicting a one-rep max from repetitions to fatigue. JOPERD 1993;64:88-90

21. Turbanski S, Schmidtbleicher D. Effects of heavy resistance training on strength and power in upper extremities in wheelchair athletes. J Strength Cond Res. 2010;24:8-16.

22. Bernard PL, Mercier J, Varray A, Prefaut C. Influence of lesion level on the cardioventilatory adaptations in paraplegic wheelchair athletes during muscular exercise. Spinal Cord. 2000;38:16-25.

23. Bhambhani Y. Physiology of wheelchair racing in athletes with spinal cord injury. Sports Med. 2002;32:23-51.

24. Bjerkefors A, Jansson A, Thorstensson A. Shoulder muscle strength in paraplegics before and after kayak ergometer training. Eur J Appl Physiol. 2006;97(5):613-8.

25. Haff G, Whitley A, Potteiger JA. Explosive exercises and sports performance. Strength Cond J. 2001;23(3):13-20.

26. Hakkinen K. Neuromuscular adaptation during strength training, aging, detraining, and immobilization. Crit Rev Phys Rehab Med. 1994;6:161-98.

27. Hakkinen K, Komi PV, Alen M. Effects of explosive type strength training on isometric force and relaxation time, electromyographic and muscle fibre characteristics of leg extensor muscles. Acta Physiol Scand. 1985;125:587-600.

28. Janssen TW, Van Oers CA, Hollander AP, Veeger HE, Van Der Woude LHV. Isometric strength, sprint power, and aerobic power in individuals with a spinal cord injury. Med Sci Sports Exerc. 1993;25(7):863-70.

29. Van Der Woude LHV, Bakker WH, Elkhuizen JW, Veeger HEJ, Gwinn T. Propulsion technique and anaerobic work capacity in elite wheelchair athletes. Am J Phys Med Rehabil.1998;77(3):222-34.

30. Van Den Berg R, De Groot S, Swart KM, Van Der Woude LH. Physical capacity after 7 weeks of low-intensity wheelchair training. Disabil Rehabil. 2010;32:1717-21. 